слову в творчестве И. Ильфа, например $\left.{ }^{13}\right)$; показано ироническое и пародийное переосмысление библейских сюжетов, имен и проч.

Особым достоинством рецензируемой монографии следует назвать обращение ученого к произведениям автора, ранее не исследовавшимся в литературоведении; подробно рассмотрены фрагменты и наброски незавершенных произведений.

В целом, монографию К. С. Позднякова можно считать свежим, актуальным исследованием поэтики прозы И. Ильфа в историко-литературном аспекте. Такое исследование будет интересным самому широкому кругу читателей: специалистам-филологам, аспирантам и студентам, всем любителям хорошего русского слова.

Елена Павловна Иванян

\title{
Библиография:
}

POZDNJAKOV, K. S.: Vozvraščenije v Odessu. Proza I. A. Il'fa. Samara: ANO «Izdatel'stvo SNC», 2018, 128 s. ISBN 978-5-6042205-2-8.

SEROV, V. V. Ėnciklopedičeskij slovar' krylatych slov i vyraženij. Moskva: OOO Izdatel'stvo «Lokid-Press», 2005, 677 s. ISBN 5-320-00323-4.

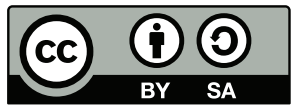

This work can be used in accordance with the Creative Commons BY-SA 4.0 International license terms and conditions (/https://creativecommons.org/licenses/by-sa/4.0/legalcode>). This does not apply to works or elements (such as images or photographs) that are used in the work under a contractual license or exception or limitation to relevant rights.

\section{O význame a hodnote (literárnohistorického) vedenia a poznania}

TATÁR, J.: Umelecký profil Štefana Krčméryho. Banská Bystrica: Belianum, 2015. 105 s. ISBN 978-80-557-0949-9.

Do prirodzenej výbavy literárnovedného výskumu patrí latentné obnovovanie vývinovo obsažných javov, ktoré sa svojou aktuálnost’ou či akútnostou prirodzene posúvajú v čase a sú navrstvované, znova prirodzene, novými reáliami, osobnostami,

13 Ibidem, s. 36-37. 
umeleckými pohybmi a všetkým tým, čo spontánne i premyslene vstupuje do umeleckej výpovede či už v generačnej podobe, alebo ako nástroj na kontinuitu pohybu vo vývinovom procese.

Spravidla to spôsobia spoločenské, kultúrne aj jubilejné udalosti, alebo ide o výsledok sústredeného výskumu konkrétneho literárnoestetického obdobia, generácie, autora a diela, ktoré prinášajú spontánne aj zámerne parciálne a potrebné vklady do latentne ústretového literárnohistorického priestoru. Získané spresnenia, doplnenia, detail, novozískaný materiál, nájdenie nepoznaného textu či inej súvislosti potrebnej na objasnenie autorského, alebo generačného pohybu v kultúre a v literatúre stanú sa prínosom. Pritom je motivácia na vznik, tvarovanie a na šírku výskumného pôdorysu konkrétneho javu rozlične iniciovaná aj určená, v jednotlivosti a vo väzbách na kontext získané informácie z výskumu ho rozširujú, čím sa spresňuje a prehlbuje poznanie, ktoré sa upevňuje aj spevňuje nielen svojím navrstvovaním, ale predovšetkým poučeným výkladom a zdôvodňovaním významu, hodnoty aj naliehavosti prínosu z výskumu do utvárania národnej a kultúrnej tradície prostredníctvom docenených hodnôt zvolených artefaktov, ich autentickej interpretácie zvlášt’ v umeleckej literatúre a pri personálnom výskume autorskej dielne.

Literárny vedec a spisovatel Jozef Tatár (1954) vymedzuje názvom publikácie Umelecký profil Štefana Krčméryho ním sledovaný vývinový záber, osobnost', druh a metódu, aby sa vedome, navyše $\mathrm{v}$ roku jubilea, svojím prieskumom včlenil do línie tých literárnovedných bádatelov, ktorí vnútorne, s empatiou, rešpektom a porozumením sa vyrovnávali so všestrannou a v kultúrnom aj literárnom živote svojej doby s myslitel'sky iniciatívnou a tvorivou osobnostou Štefana Krčméryho $(1892-1955)$.

Autor publikácie venovanej literárnej osobnosti Krčméryho sa $\mathrm{k}$ dejom vo vývine slovenskej spoločenskej a kultúrnej pamäti vyjadril v prácach Básnická medzigenerácia (od realizmu k moderne) (2002), Básnik a láska (2006), Z poézie troch storočí (2013) a inštruktážne v spoluautorstve s Júliusom Lomenčíkom v Interpretačnom minime. $Z$ modernej slovenskej poézie (2002).

Rozhodnutie Jozefa Tatára vstúpit’ do rozvetvenej bádatel'skej spoločnosti okolo Štefana Krčméryho je z jeho literárnovedného postu zámer sústredit’ do celku osobný viacročný výskum aj s parciálnymi výstupmi, tie utvorili kompozičnú os rekonštrukcie formovania osobnostného profilu Štefana Krčméryho. Termíny profil a portrét odlišujú metódy aj ambície, rozsah aj híbka prístupu k osobnosti. Termín profil v koncepte Jozefa Tatára naznačuje výrez z budúcej syntézy, torzo aj prierez, univerzum aj osobitost' ako súčasti budúceho celostného a vytaženého dotyku s autorom a jeho tvorbou.

Umelecký profil Štefana Krčméryho komorne, argumentačne presvedčivo sleduje straty a prínosy času a dejov do života Krčméryho a do politických a spoločenských premien, ktoré vplývali na slovenskú kultúru a literatúru, otázky jazyka a národnej 
identity po vzniku Československej republiky, pritom neobíde ani udalosti od polovice minulého storočia tak, aby publikácia reagovala a dala odpovede na absenciu syntetizujúceho výkladu tvorivého potenciálu Krčméryho, na jeho „širokospektrálnost", na umeleckú, vedeckú, publicistickú a osvetovú činnost. ${ }^{1}$

Kým sa tak jeho pričinením stane, spresňuje Jozef Tatár svoju ambíciu, „Náš monografický záber naplñame dvojlíniovo - tematizovaním nových problémov a systematizovaním doterajších výskumných záverov s konfrontačnou a aktualizačnou participáciou nášho čítania“"2 Autor pokračuje pri precizované a vymedzovaní koordinátov pre publikáciu: „Z textového aspektu monografia zahŕña tematicky a žánrovo orientovaný výber $z$ autorovej básnickej a prozaickej tvorby, s výskumným dôrazom na tematicko-motivickú štruktúru a poetologické zložky. [...]. Heuritický výskum (archívne pramene - predovšetkým korešpondencia) a interdisciplinarita zameraná najmä na filozofický, sociologický a psychologický kontext sú limitované mimoliterárnovednými cielmi: identifikácia textov z aspektu umelecko-estetického progresu na pozadí literárnovývinových súvislostí..."3

Dostupný krčméryovský výskum má bohaté zázemie, ale Jozef Tatár naznačuje, „Za jedinú prácu monografického charakteru možno považovat biograficko-bibliografický portrét autora Slovo čisté s podnázvom Život a dielo Štefana Krčméryho v dokumentov (1979) od A. Matovčíka". Pripomenie aj sa odvoláva na viacero literárnych historikov, ale zaujali ho Zamborove interpretácie Krčméryho poézie, práce Anny Zelenkovej Slovenská prozódia a verzifikácia v rukopise Štefana Krčméryho (1935) vydaná v roku 2006 a Veci na dne duše. Dva neznáme rukopisy Štefana Krčméryho (2012). Za autora možno doplnit', po vydaní Umeleckého profilu Štefana Krčméryho zverejnil Anton Baláž literárne vyrozprávaný osobný príbeh Štefana Krčméryho v románe Povedz slovo čisté (2018).

Teda význam a rešpekt, vedenie a poznanie, univerzálne a jedinečné, asi tak bude účinné prijímat’ a docenit’ postup Jozefa Tatára k rozsiahlemu celku krčméryovského autorského materiálu. Za epicentrum osobného a spoločenského výkladu reálií spojených s osobnostou Štefana Kčméryho, za prínos dostupných analýz a za osobne motivované poetologické, sémantické a emotívno-morálne iniciované interpretácie básnických textov z viacerých zbierok Krčméyho si Jozef Tatár zvolil za východisko, hovorí o zlomovom období, zázemie vytvorené druhým a tretím desatročím minulého storočia. Pripomenuté desat'ročia spojili Krčméryho so Slovenskými pohladmi, s obhajobou rigoróznej práce Príspevok k dejinám básnickej školy Štúrovej (Univerzita

\footnotetext{
1 TATÁR, J.: Umelecký profil Štefana Krčméryho. Banská Bystrica: Belianum, 2015, s. 4.

2 Tamže

3 Tamže, s. 5-6.

4 Tamže, s. 4 .
} 
Karlova, 1930) a s osobnostami jemu tak dôvernými, aby sa bolo možné sústredit' na Krčméryho korešpondenciu, na za vec národnej svojbytnosti zaujatej publicistiky, či ide o odkazy na iné písomnosti zo spomenutých rokov aj preto, aby sa v Tatárovom výklade sformovala a zosúladila osobná a profesijná cesta s umeleckým, mravným a nazeracím poznaním výnimočného Štefana Krčméryho a toto „zlomové obdobie“ zotrvalo v centre literárnovedného prostredia v Tatárovom rozhladenom prieniku do Umeleckého profilu Štefana Krčméryho.

Pri výklade a interpretácii okolností života a tvorby, občianskeho a národného vymedzovania sa Krčméryho sa Jozef Tatár koncentruje na umelecké texty a na početný sekundárny materiál, predovšetkým na roky Krčméryho pôsobenia v Slovenských pohladoch z dvadsiatych rokoch, na korešpondenciu, zápisky, publicistické zdroje z toho aj nasledujúceho desatročia. Jozef Tatár činí tak na prospech „neučebnicového“, širšieho a prenikavejšieho poznanie zázemia jeho osobnosti, čo zužitkuje pri interpretovaní poetiky, sémantiky, symbolov, motívov, statusu lyrického subjektu básnika, sám ho označil za romantika, dodajme, dôsledného a kultivovaného humanistu.

Za objekt interpretácie si zvolil Jozef Tatár básnické knihy, alebo jedinú báseň či prózu, aby nuansovým pohybom po veršoch, vetách a významových celkoch mohol čitatel' docenit jemné, premyslené a s rešpektom komparované závery dotýkajúce sa spoločenských a osobných dejov, napríklad aj nenáhlivým prenikaním do genézy a zmien v nazeraní na existenciu a dobový svet, ktoré si Krčméry v mladosti osvojil zo štúdia F. Nietzscheho a A. Shopenhauerových spisov.

Krčméryho zložitá osobnostná línia našla v Tatárovom zhodnocovaní a výklade ním aktualizovaného básnického, prozaického, publicistického textu, ale i pri odkazoch na jeho prekladovú slovanskú a neslovanskú básnickú tvorbu oporu v samotnom Štefanovi Krčmérym, „Ұe nesporné, že $v$ rámci osobných ašpirácií, životných aj pracovných cielov, mal zadefinovaný ideálny sebaobraz národu oddanej, vzdelanej, uznávanej, potentnej a repezentatívnej osobnosti svojej doby. [...], podla Krčméryho osobnej angažovanosti nám vychádzajú maximálne výkonové ašpirácie, dokazujúce aj preceňovanie sa, čo akiste počas sebahodnotenia spôsobovalo nazeranie týchto cielov do kategórie dosiahnutých úspešných výsledkov a mohlo viest' $k$ psychickej labilite osobnosti."

Záujem o osobnost’ a tvorbu Štefana Krčméryho má v koncepte genézy a utvárania sa jeho umeleckého (poézia, próza, preklad) profilu pre Jozefa Tatára, ako to naznačil na počiatku, dve línie. Prvú líniu sprevádza rekonštrukcia dejinno-spoločenských procesov navodených geopolitickými zmenami na prelome devätnásteho a začiatku dvadsiateho storočia, udalost’ami a vážnymi národnými problémami (jazyk, identita, 
svojbytnost', samostatnost') spojené so vznikom Československej republiky, zvlášt' dvadsiate roky a Krčméryho názorové formovanie Slovenských pohladov, jeho v danej situácii názorom a postojmi aktívna spoločenská publicistika. Druhá línia sa nasycuje Tatárovými významovými (romantické gesto) a poetologicky dopovedanými interpretáciami Krčméryho poézie (od realizmu po modernu), dôvodením jeho záujmu o minulost' tematizovanú v próze a šírkou prekladatel'ského záberu v časti K slovensko-slovansko-európskej dimenzii tvorby s pointou „[...] možno Š. Krčméryho vnímat ako harmonizátora idey slovanskosti, európskosti, ale aj česko-slovenských vztahov v medzivojnovej Československej republike".6

Obidve literárnohistoricky a textovo vedené línie upäté na vývinové pohyby nebránili Jozefovi Tatárovi v poučenej kritickej reflexii, tak ju označil sám. Tá sa odvíjala od jeho profesijnej zorientovanosti v slovenskej medzivojnovej literatúre a v dobovej literárnej vede, no ukazuje sa aj v osobnej zahladenosti do poézie Štefana Krčméryho. Umelecký profil Štefana Krčméryho vstúpil do už jestvujúcej a dostupnej výskumnej zásobnice ako čast' z celku s poslaním oslovit’ odbornú a kultúrnu verejnost' Tatárovým videním a vedením, poznaním a porozumením autentickému šperku z dejín modernej slovenskej literatúry v európskom kultúrnom prostredí.

Viera Žemberová

\section{Literatúra:}

TATÁR, J.: Umelecký profil Štefana Krčméryho. Banská Bystrica: Belianum, 2015. $105 \mathrm{~s}$. ISBN 978-80-557-0949-9.

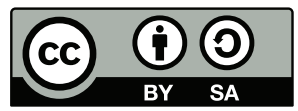

This work can be used in accordance with the Creative Commons BY-SA 4.0 International license terms and conditions (<https://creativecommons.org/licenses/by-sa/4.0/legalcode>). This does not apply to works or elements (such as images or photographs) that are used in the work under a contractual license or exception or limitation to relevant rights.

https://doi.org/10.5817/OS2020-3-12

\section{Podoby skazu}

KOSÁKOVÁ, D.: Podoby skazu. K jedné linii moderní prozaické tvorby. Praha: Filozofická fakulta UK v Praze, 2019. 230 s. ISBN 978-80-7308938-2.

Publikácia Hany Kosákovej s názvom Podoby skazu. K jedné linii moderní prozaické tvorby je venovaná naratívnej stratégii, navodzujúcej dojem spontánneho hovoreného rozprávania, ktorú pod názvom skaz vypracoval v druhom desat’ročí 20. storočia 